\title{
Response of Vegetation and Soil Seed Bank to Habitat Diversity in Riyadh desert, Central Saudi Arabia
}

\author{
Kamal M. Zayed \\ Botany Departmen, Faculty of Science, \\ Cairo University, Giza, Egypt.
}

Zayed, K. M. 2000. Response of Vegetation and Soil Seed Bank to Habitat Diversity in Riyadh desert, Central Saudi Arabia. Taeckholmia 20(1):81-94.

\begin{abstract}
Four ecologically different habitats within Riyadh desert (Central Saudi Arabia) were studied. Three different plant communities dominated by Pulicaria crispa, Lycium shawii and Farsetia aegyptia form the vegetation units inhabiting the first habitat represented by depressions and wadi terraces with deep and finely textured soil. The seed content in the upper $2 \mathrm{~cm}$ of these soils ranged between 38304 and 71484 seeds $/ \mathrm{m}^{2}$. The second habitat is represented by the runnels dissecting gravelly areas with shallow and coarse-textured soil. This habitat supported the growth of two plant communities dominated by perennial grassland species Cenchrus ciliaris and Lasiurus scindicus with soil seed content amounting to 14855 and 9000 seeds $/ \mathrm{m}^{2}$ in the two communities respectively. Sandy plains represent the third investigated habitat which is inhabited by Rhazya stricta community with soil seed content amounting to $41580 \mathrm{seeds} / \mathrm{m}^{2}$. Saline soils supporting growth of the communities dominated by salt tolerant species Tamarix nilotica and Zygophyllum album formed the fourth investigated habitat. The counted seeds in the upper $2 \mathrm{~cm}$ of the soil were 53352 and $15624 \mathrm{seeds} / \mathrm{m}^{2}$ in the above communities, respectively. The present study showed that the emerged seedlings from the soils collected from the recognized communities represented a low value ranged from 0.92 to $3.38 \%$ out of the total estimated seed bank.
\end{abstract}

Key words : Soil seed bank, Riyadh desert.

\section{Introduction}

Up to the end of the 1970s, our knowledge of vegetation conditions in the Central region of Saudi Arabia was restricted largely to the studies of Vesey-Fitzgerald (1957); Khattab and El-Hadidi, 1971 and Migahid and El-Sheikh (1977). The study of vegetation of this region has received more attention in the last years by other investigators (Yousif and ElSheikh, 1982; Bairele et al., 1985; El-Farraj et al., 1997 and El-yemeni \& Zayed, 1999).

Although the literature concerned with the evaluation of the seeds naturally occurring in arable and desert soils are numerous and expanding rapidly throughout in the world (Adbel-Rahman \& Batanouny, 1959; Malone, 1967; Roberts and Feast, 1972; Zayed, 1980; Egly, 1986; Kemp, 1989; Batanouny et al., 1991 and Emad, 1997), very little is known about the viable seeds buried into the desert soil of Saudi Arabia, (ElYemeni and El-Farraj, 1995).

The goal of the present study is to evaluate the vegetation and seed bank in such arid region (characterized by a mean annual rainfall of $11.5 \mathrm{~mm}$ ) as affected by habitat diversity.

\section{Materials and Methods}

The Present investigation was undertaken during a period extending from November, 1997 to June, 1998. The vegetation characteristics were derived from the study of 10 
representative stands for each distinguished community. The stands were randomly chosen. Recorded plant species were rated according to Braun-Blanquet (1964). Two scales were applied: abundance-dominance scale (combining the abundance and cover of the species) and the sociability scale. The features of the habitats supporting the different investigated communities were also described.

Five replicates of soil samples were collected from the rhizosphere region within the habitats of each community type for the determination of soil texture, carbonate and organic matter content. Soil texture was determined by Bouygacos hydrometer method. Soil organic matter was determined according to Allen et al., (1974) whereas carbonate content was determined applying the method adopted by Piper (1950).

For the determination of seed bank, soil samples were collected in January 1998 from the uppermost $2 \mathrm{~cm}$ of the soil, sampling area was $25 \times 25 \mathrm{~cm}$. Thirty two replicates of soil samples were collected from each community, and stored in cotton bags. In the laboratory, the soil samples were air-dried, mixed thoroughly and sieved through $2 \mathrm{~mm}$ sieve mesh to separate the large pebbles and plant debris. After that, the weight of sieved soil per $\mathrm{m}^{2}$ surface area was determined. Seed bank was estimated by sowing and floating methods.

In sowing method, adopted by Roberts \& Neilson, (1982), alumenium trays with dimensions of 50x25x10cm were used. Trays were filled with sand and covered with 2 cm thick sterilized soil (oven-dried for 24 hrs at $105{ }^{\circ} \mathrm{C}$ ) to get rid of the contained viable propagules. Collected soil samples were then spread homogeneously over the surface of the sterile soil to have a thickness of $2 \mathrm{~cm}$. Four replicates were used for each community. Two trays with sterilized soil only were used as control. The trays were irrigated twice a week and the emergence of the seedlings was counted at each second day. This experiment was carried out in a greenhouse under temperatures ranged from (16 to $25.6 \pm$ $\left.3^{\circ} \mathrm{C}\right)$.

Floating method was applied to find out the total number of seeds contained in a certain area of soil. The procedure was done according to Visser \& Wentzel, (1980). Five replicates each of $5 \mathrm{gm}$ soil were shaked well in $25 \mathrm{ml}$ of $40 \% \mathrm{CaCl}_{\mathrm{a}}$ for few minutes. All the floating materials were separated and received over a very narrow sieve. The floating materials were thoroughly washed with water, air- dried and examined microscopically.

\section{Results}

\section{Climate}

Data presented in Table (1) show that the study area is subject to an obvious climatic aridity. This aridity is manifested by the recorded low rainfall with an annual mean of $11.5 \mathrm{~mm}$, high temperature especially during the long dry summer months with a mean ranging from 31.6 to $35.6{ }^{\circ} \mathrm{C}$ and low relative humidity ranging from 10 to $50 \%$. Consequently, the evaporative power of the atmosphere is high with a mean of 10.35 $\mathrm{mm} /$ day. This general aridity of the climate reflects and exerts its effect on the vegetation of the study area. 
Table (1): Climatic pecularities of Riyadh meteorological station (1987-1996) "Compiled from Meteorological \& Environmental Protection Administration, K.S.A”.

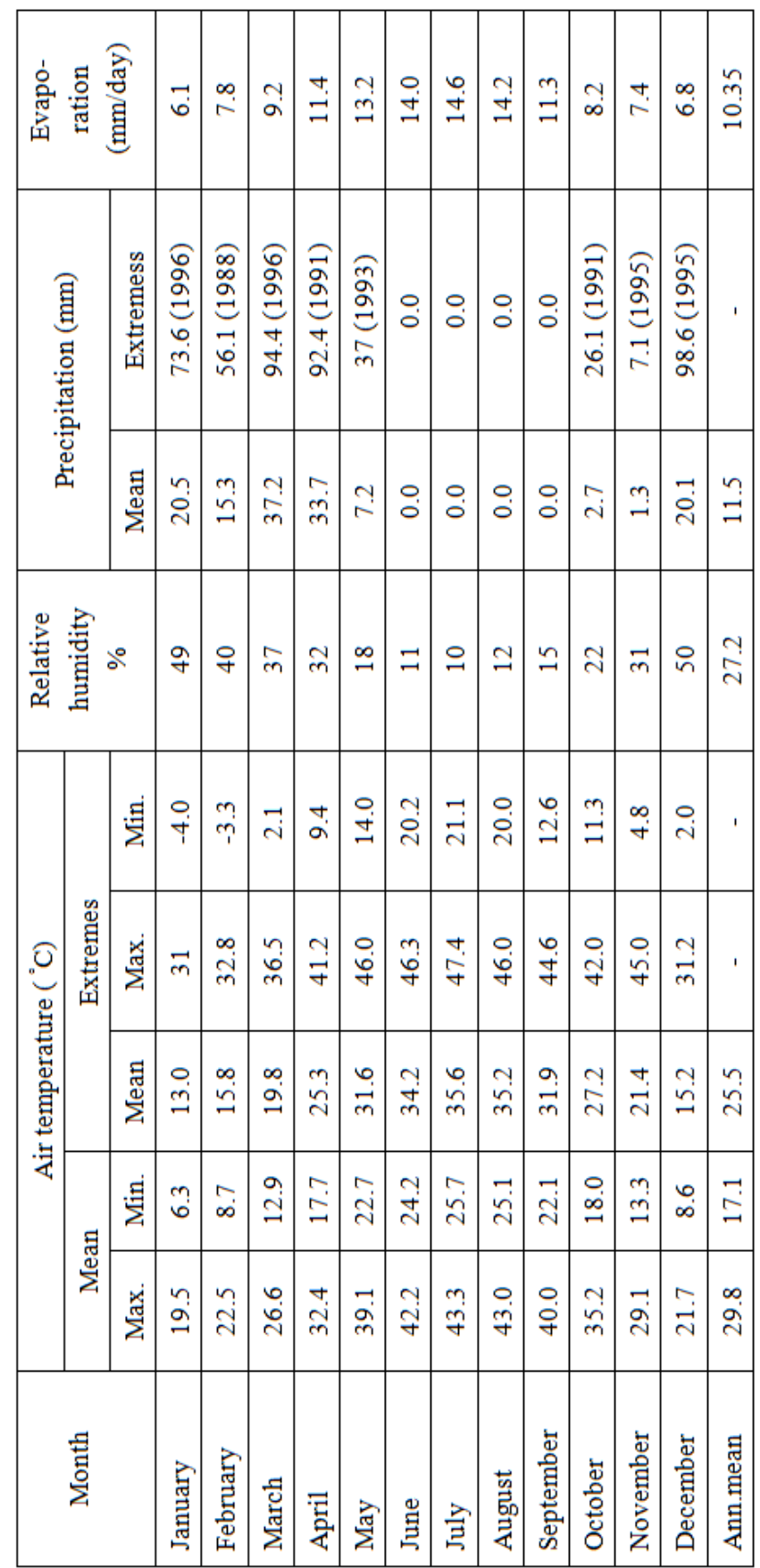




\section{Edaphic factors}

The edaphic characteristics of the studied habitats are shown in Table (2). Physical analysis of the collected soil samples shows a great variability among the soils of the different investigated habitats. Soils collected from depressions and terraces are loamy sand with relatively high percentage of fine sediments (silt and clay) possessing a high water-retaining power. These fine sediments ranged between $28 \%$ (in the localities inhabited by Farsetia aegyptia community type) and $44 \%$ in those inhabited by Francoeuria crispa community type.

On the other hand, soils collected from the affluent runnels are sandy with very low percentage of fine sediments amounting to $6 \%$ in the runnels supporting vegetation inhabited by Lasiurus scindicus and $12 \%$ in those occupied by Cenchrus ciliaris community type. The soils of sandy plains and saline habitats are loamy sand with lesser fine sediments as compared to that of the depressions and terraces. The total carbonate content of the studied soils is generally low ranging from 0.150 to $0.285 \%$.

The organic matter content in the investigated soils is commonly low. The lowest value of $0.32 \%$ is recorded in the soils collected from the runnels occupied by Cenchrus ciliaris community, whereas soils of depressions supporting vegetation dominated by Francoeuria crispa contain a relatively high organic matter amounting to $2.4 \%$.

\section{Vegetation and seed Bank}

\section{A) Communities inhabiting depressions and terraces}

\section{1- Francoeuria crispa community type.}

This community inhabits depressions of deep alluvial fine-textured soil. Some of these depressions appear to be man-made especially along the roads. The floristic composition of this community type includes 14 perennial and 17 ephemeral species (Table 3). Plant cover is comparatively thick ranging from 30 to $75 \%$ in the different investigated stands. The vegetation shows some sort of stratification. The shrub layer comprises: Acacia tortolis $(\mathrm{P}=20 \%)$, Ochradenus baccatus, Ziziphus spina-christi and Calotropis procera $(\mathrm{P}=10 \%)$. Layer of dwarf shrubs and perennial herbs is the most conspicuous one. It includes the dominant species Francoeuria crispa (P 100\%) together with the following associates: Zilla spinosa and Dichanthium annulatum $(\mathrm{P}=70 \%)$, Lasiurus scindicus $(\mathrm{P}=50 \%)$, Cenchrus ciliaris and Farsetia longisiliqua $(\mathrm{P}=20 \%)$, Launaea nudicaulis $(\mathrm{P}=10 \%)$ and the two succulent species namely; Zygophyllum coccineum $(\mathrm{P}=40 \%)$ and Suaeda fruticosa $(\mathrm{P}=30 \%)$.

The ground layer (height of $30 \mathrm{~cm}$ or less) is composed of Citrullus colocynthis $(\mathrm{P}=30 \%)$ and the ephemerals: Schismus barbatus $(\mathrm{P}=100 \%)$, Malva parviflora and Polygonum patulum $(\mathrm{P}=80 \%)$, Melilotus indica $(\mathrm{P}=70 \%)$ and Lactuca serriola $(\mathrm{P}=50 \%)$ Plantago amplexicaulis $(\mathrm{P}=40 \%)$, Chenopodium murale, Lolium rigidum, Phalaris minor and Urospermum pecroides $(\mathrm{P}=30 \%)$. Other associated ephemerals have a presence value of $20 \%$ or less.

The relatively high cover percentage of the vegetation of this community together with the high amount of fine soil fragments cause an increase of the reserve soil seeds which attained a value of 71484 seeds $/ \mathrm{m}^{2}$ in the upper $2 \mathrm{~cm}$ of the soil. Meanwhile, 2420 seedlings $/ \mathrm{m}^{2}$ were emerged from the soil collected from this habitat. However, the emerged seedlings represent only $3.38 \%$ out of the total counted seeds. 
Table (2): Soil analysis, emerged seedlings and total seeds per sq.m in the upper $2 \mathrm{~cm}$ of soils collected From different communites inhabiting different habitats in Riyadh desert.

\begin{tabular}{|c|c|c|c|c|c|c|c|c|c|}
\hline \multicolumn{2}{|c|}{ 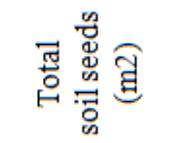 } & $\underset{⿱}{\stackrel{+}{+}}$ & \begin{tabular}{l} 
N \\
\multirow{\infty}{\infty}{} \\
$\infty$ \\
$\infty$
\end{tabular} & $\begin{array}{l}\text { ¿ } \\
\text { M } \\
\infty \\
m \\
m\end{array}$ & 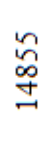 & 응 & $\begin{array}{l}\circ \\
\stackrel{\infty}{2} \\
\stackrel{7}{\forall}\end{array}$ & $\begin{array}{l}\text { ñ } \\
m \\
\text { ñ }\end{array}$ & $\begin{array}{l}\stackrel{+}{d} \\
\stackrel{\sigma}{\sim}\end{array}$ \\
\hline \multicolumn{2}{|c|}{ 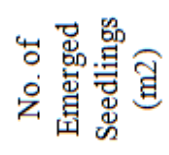 } & $\stackrel{\stackrel{ }{+}}{\sim}$ & $\stackrel{ }{\stackrel{ }{ }}$ & 웅 & $\stackrel{\infty}{\infty}$ & $\stackrel{\circ}{\sim}$ & 䚟 & ్ర & 유 \\
\hline \multicolumn{2}{|c|}{ ఠ̊ ஓ } & $\stackrel{\circ}{\stackrel{n}{\circ}}$ & 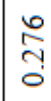 & $\begin{array}{l}0 \\
\stackrel{1}{a} \\
0\end{array}$ & $\begin{array}{l}\text { Jै } \\
\text { ণุ } \\
0\end{array}$ & $\stackrel{2}{\stackrel{2}{2}}$ & $\begin{array}{l}\text { o } \\
\text { ปุ } \\
\text { ( }\end{array}$ & กิ & त̂ \\
\hline \multicolumn{2}{|c|}{ 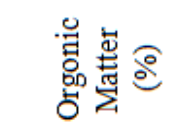 } & $\stackrel{\text { ơ }}{i}$ & $\stackrel{ }{\stackrel{ }{-}}$ & ๙̊ & $\frac{}{\circ}$ & กั & テั & ๙ૂ & $\stackrel{n}{n}$ \\
\hline \multirow{3}{*}{ 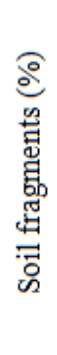 } & 冠 & $\nabla$ & 윽 & $\infty$ & $\nabla$ & $\nabla$ & $\nabla$ & 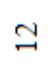 & $\infty$ \\
\hline & $\stackrel{ \pm}{\square}$ & 우 & $\stackrel{\sim}{\sim}$ & 이 & $\infty$ & $N$ & $\stackrel{\sim}{ }$ & \pm & $\stackrel{9}{-}$ \\
\hline & $\begin{array}{l}\text { 菏 } \\
\text { مै }\end{array}$ & 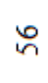 & to & $\mathbb{N}$ & $\infty_{\infty}^{\infty}$ & よ゙ & + & $\underset{\perp}{ \pm}$ & $\Re$ \\
\hline \multicolumn{2}{|c|}{ 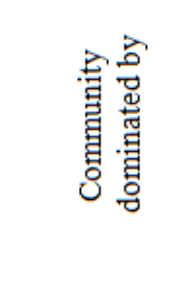 } & 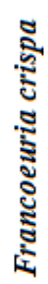 & 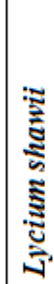 & 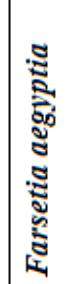 & 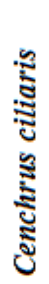 & 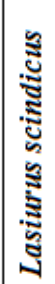 & 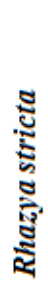 & 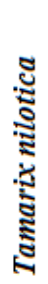 & 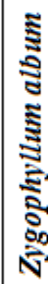 \\
\hline \multicolumn{2}{|r|}{ 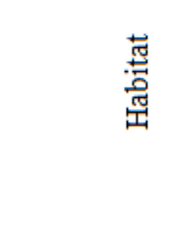 } & \multicolumn{3}{|c|}{ 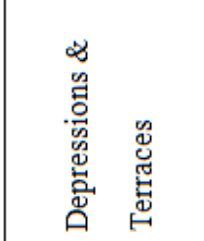 } & \multicolumn{2}{|c|}{ 恚 } & 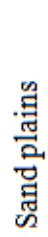 & \multicolumn{2}{|c|}{ 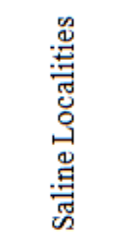 } \\
\hline
\end{tabular}


Table 3: Vegetation characteristics of the plant communities inhabiting different habitats within Riyadh desert, Saudi Arabia. $\mathrm{AB}=$ Combined scale of Braun, Blanquet, $\mathrm{P}=$ presence value (\%).

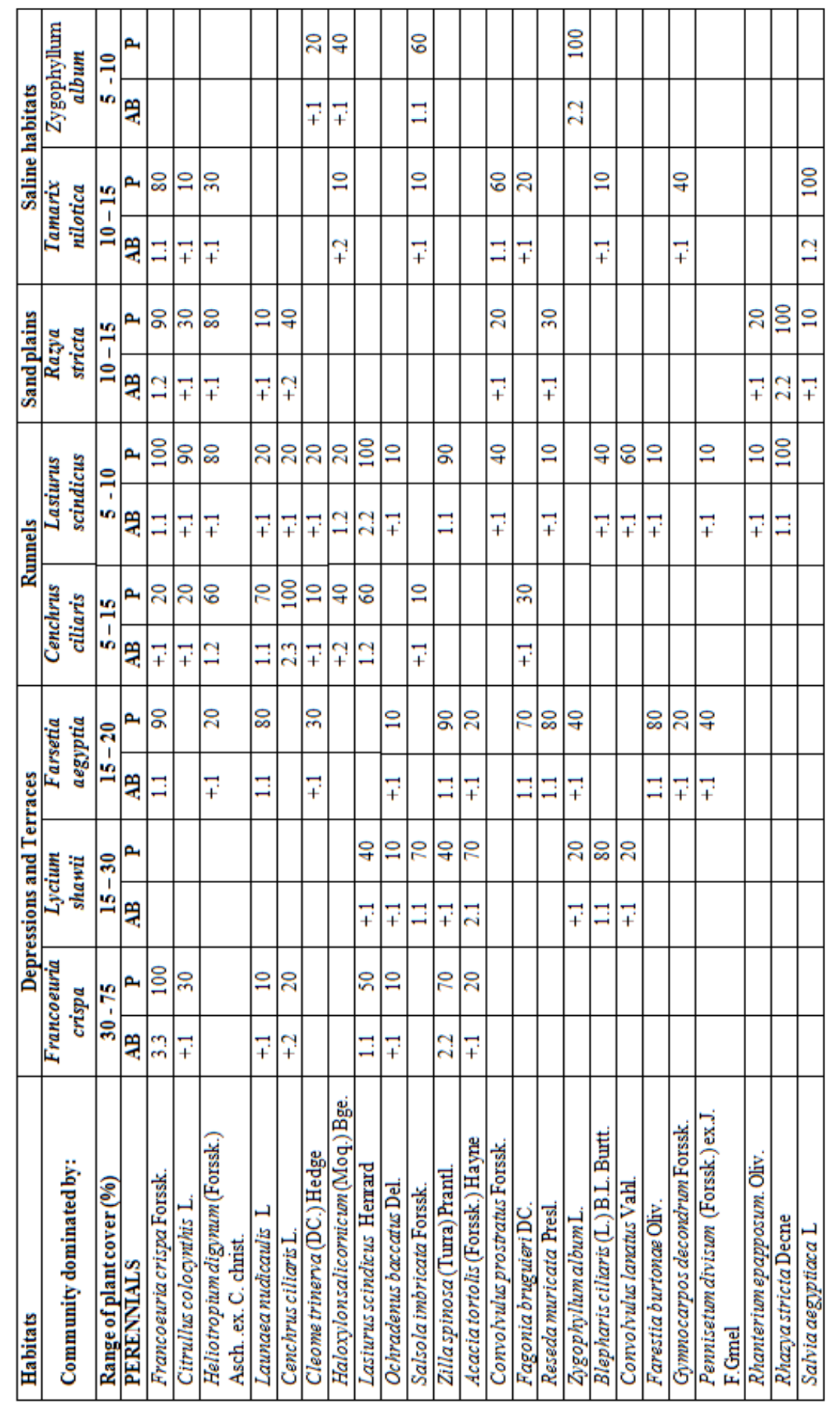


Table 3: Cont.

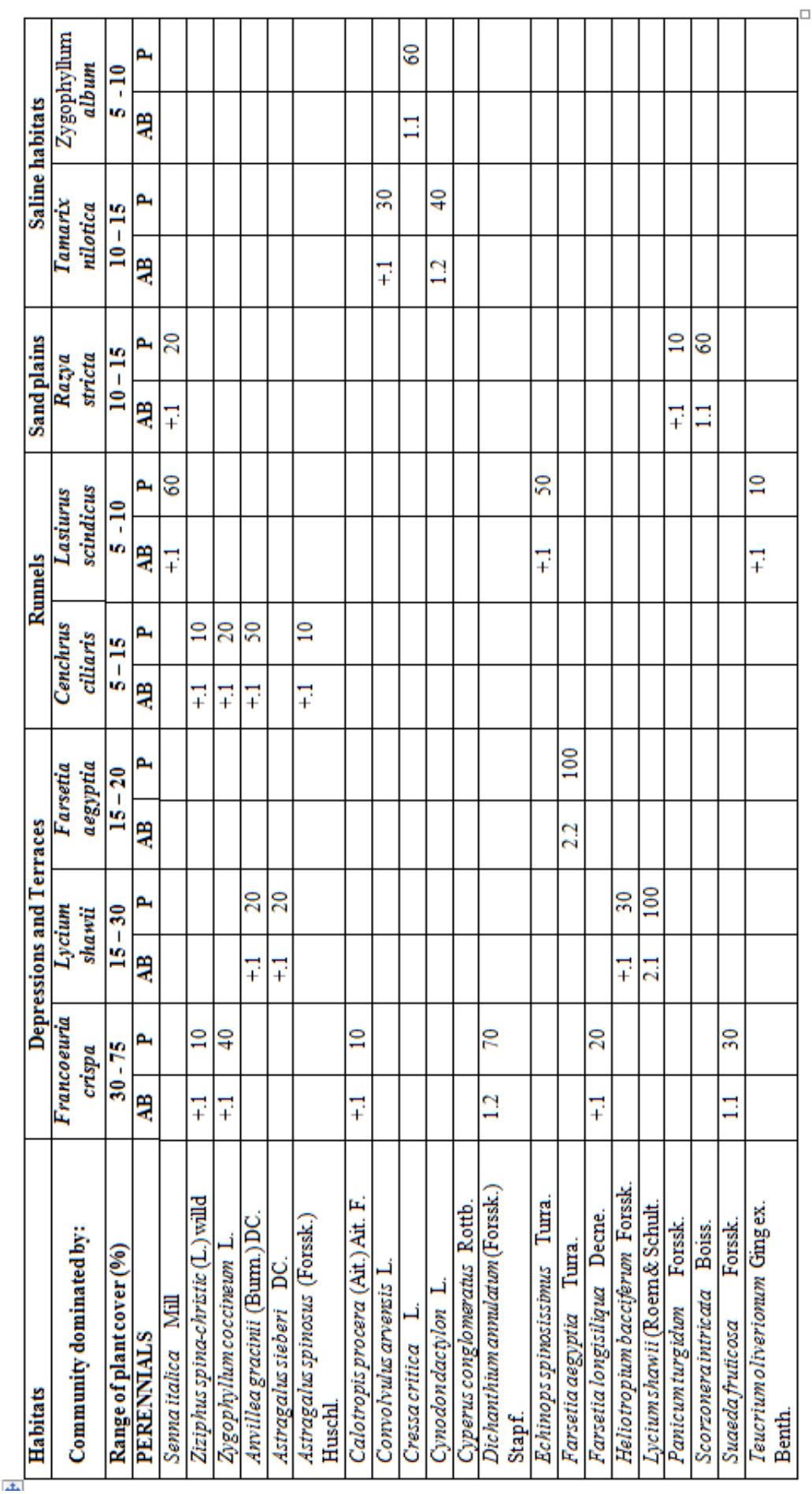


K. M. Zayed

Table 3: Cont.

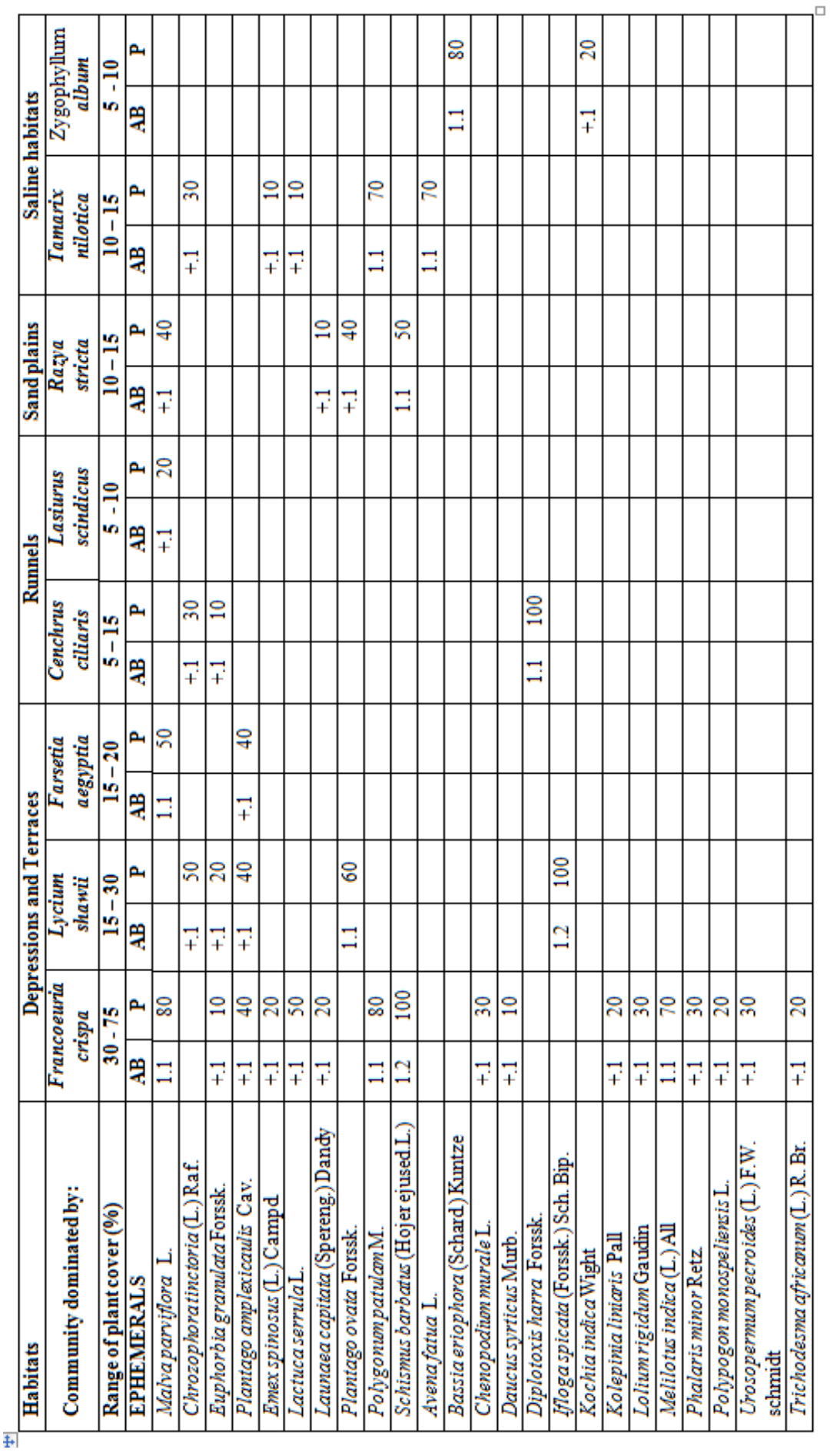




\section{2 - Lycium shawii community type}

This community is widespread in the wadi terraces of the study area where the soil is more or less deep and fine-textured. The dominant species Lycium shawii shows a stunted growth which could be attributed to the intensive grazing. The plant cover is relatively low ranging from 15 to $30 \%$. Twelve perennial and five ephemerals constitute the vegetation of this community type exhibiting some sort of stratification (Table 3 ). The tree layer is represented by Acacia tortolis $(\mathrm{P}=70 \%)$. The dominant species Lycium shawii $(\mathrm{P}=100 \%)$ and sparce individuals of Ochradenus baccatus $(\mathrm{P}=10 \%)$ constitute the shrub layer. Layer of dwarf shrubs and perennial herbs includes: Blepharis ciliaris $(\mathrm{P}=80 \%)$, Salsola imbricata $(\mathrm{P}=70 \%)$, Zilla spinosa and Lasiurus scindicus $(\mathrm{P}=40 \%)$, Heliotropium bacciferum ( $\mathrm{P}=30 \%)$, Zygophyllum album, Anvillea gracinii Convo-lvulus lanatus and Astragalus sieberi $(\mathrm{P}=20 \%)$. The ground layer includes the ephemerals: Ifloga spicata $(\mathrm{P}=100 \%), \quad$ Plantago ovata $(\mathrm{P}=60 \%)$, Chrozophora tinctoria $(\mathrm{P}=50 \%)$, Plantago amplexicaulis $(\mathrm{P}=40 \%)$ and Euphorbia granulata $(\mathrm{P}=20 \%)$.

Soil samples collected from the upper $2 \mathrm{~cm}$ of this community contained 58752 seeds $/ \mathrm{m}^{2}$, while the emerged seedlings attained a value of 1210 seedlings $/ \mathrm{m}^{2}$.

\section{3- Farsetia aegyptia community type}

This community has a limited distribution in the study area. It occupies shallow depressions with plant cover ranges between 15 and 20\%. Fourteen perennial and two ephemeral species constitute the vegetation dominated by Farsetia aegyptia. (Table 3). Acacia tortolis $(\mathrm{P}=20 \%)$ and Ochradenus baccatus $(\mathrm{P}=10 \%)$ comprise the shrub layer. The most prominant layer is that composed of dwarf shrubs and perennial herbs which includes: Farsetia aegyptia $(\mathrm{P}=100 \%)$ together with the following associates: Francoeuria crispa and Zilla spinosa $(\mathrm{P}=90 \%)$, Launaea nudicaulis, Reseda muricata and Farsetia burtonae $(\mathrm{P}=80 \%)$, Fagonia bruguierei $(\mathrm{P}=70 \%)$, Pennisetum divisum and Zygophyllum album $(\mathrm{P}=40 \%)$, Gymnocarpos decandrum and Heliotropium digynum $(\mathrm{P}=20 \%)$.

The two recorded ephemerals; Malva parviflora (P=50\%) and Plantago amplexicaulis $(\mathrm{P}=40 \%)$ constitute the ground layer.

The estimated seed bank attained a value of 38304 seeds $/ \mathrm{m}^{2}$, whereas sowing of the soil samples collected from this community gave rise to 670 seedlings $/ \mathrm{m}^{2}$.

\section{B- Communities inhabiting affluent runnels}

\section{1- Cenchrus ciliaris community type}

This grassland community has an open vegetation with plant cover not exceeding $15 \%$. The community occupies runnels of varying width which dissect gravelly slopes that are covered with rocks of various sizes. The habitats of the runnels are subjected to severe erosion due to the combined action of deficiency of water revenue and grazing. The number of recorded species is fourteen perennials and three ephemerals (Table 3). Shrub layer is represerted by a single individual of Ziziphus spina-christi. The most prominent layer is that formed of dwarf shrubs and perennial herbs including Cenchrus ciliaris $(\mathrm{P}=100 \%)$ and the following associates: Launaea nudicaulis $(\mathrm{P}=70 \%)$, Lasiurus scindicus and Heliotropium digynum ( $\mathrm{P}=60 \%)$, Anvillea gracinii $(\mathrm{P}=50 \%)$, Haloxylon salicornicum $(\mathrm{P}=40 \%)$, Fagonia bruguieri $(\mathrm{P}=30 \%)$, Zygophyllum coccineum and Francoeuria crispa 
( $\mathrm{P}=20 \%)$. The other associates have a presence value of $10 \%$. The ground layer includes Citrullus colocynthis $(\mathrm{P}=20 \%)$ and the ephemerals: Diplotaxis harra $(\mathrm{P}=100 \%)$, Chrozophora tinctoria $(\mathrm{P}=30 \%)$ and Euphorbia granulata $(\mathrm{P}=10 \%)$.

The total buried seeds in the upper $2 \mathrm{~cm}$ of soils collected from this habitat attained a value of $14855 / \mathrm{m}^{2}$ while the emerged seedlings are $180 / \mathrm{m}^{2}$.

\section{2- Lasiurus scindicus community type}

The community dominated by this tussock-forming grass is characterized by a thin vegetation with plant cover ranges from 5 to $10 \%$. Twenty one perennials and only one ephemeral species are recorded in this community (Table 3). Trees and shrubs are completely absent. The dwarf shrubs and perennial herbs include the dominant species Lasiurus scindicus ( $\mathrm{P}=100 \%$ ) together with the following associates: Francoeuria crispa and Rhazya stricta $(\mathrm{P}=100 \%)$, Zilla spinosa $(\mathrm{P}=90 \%)$ Heliotropium digynum $(\mathrm{P}=80 \%)$, Senna italica and Convolvulus lanatus $(\mathrm{P}=60 \%)$, Echinops spinosissums $(\mathrm{P}=50 \%)$, Convolvulus prostratus and Blepharis ciliaris $(\mathrm{P}=40 \%)$. Other recorded associates have low presence value not exceeding 20\%. The ground layer is formed of Citrullus colocynthis $(\mathrm{P}=90 \%)$ and the ephemeral Malva parviflora $(\mathrm{P}=20 \%)$.

Seed bank of only 9000 seeds $/ \mathrm{m}^{2}$ is estimated in the soil samples collected from this habitat. Applying sowing method, 150 seedling $/ \mathrm{m}^{2}$ are recorded.

\section{C - Community inhabiting sandy plains}

\section{Rhazya stricta community type}

This community abounds on sandy plains with deep and coarsely textured soil in the study area. The dominant plant Rhazya stricta forms small-sized mounds of fine detritus around itself. Trees and shrubs are lacking in the vegetation of this community which consists of thirteen perennial and four ephemeral species (Table 3).

Layer of dwarf shrubs and perennial herbs includes Rhazya stricta $(\mathrm{P}=100 \%)$ together with the following associates: Francoeuria crispa $(\mathrm{P}=90 \%)$, Heliotropium digynum $(\mathrm{P}=80 \%)$, Scorzonera intricata $(\mathrm{P}=60 \%)$, Cenchrus ciliaris $(\mathrm{P}=40 \%)$. The other associated perennials have a presence value of $30 \%$ or less.

Regarding the seed bank of the soil collected from the sandy plain habitat, a values of 41580 seeds $/ \mathrm{m}^{2}$ and 830 seedlings $/ \mathrm{m}^{2}$ are estimated.

\section{D- Communities inhabiting saline habitats}

\section{1- Tamarix nilotica community type}

The dominant species Tamarix nilotica is a salt-secreting species that dominates plant community abounds on wet saline localities in the study area. Twelve perennial and five ephemeral species constitute the vegetation dominated by Tamarix nilotica which forms the shrub layer $(\mathrm{P}=100 \%)$. The layer of dwarf shrubs and perennial herbs includes: Salvia aegyptiaca $(\mathrm{P}=100 \%)$, Francoeuria crispa $(\mathrm{P}=80 \%)$, Convolvulus prostratus $(\mathrm{P}=60 \%)$, Gymnocarpos decandrum and Cynodon dactylon $(\mathrm{P}=40 \%)$, Heliotropium digynum and Convolvulus arvensis $(\mathrm{P}=30 \%)$, Fagonia bruguieri $(\mathrm{P}=20 \%)$, Blepharis ciliaris, Salsola imbricata and Haloxylon salicorncum $(\mathrm{P}=10 \%)$. The ground layer includes Citrullus colocynthis $(\mathrm{P}=10 \%)$ and the ephemerals: polypogon monspeliensis and Avena fatua 
( $\mathrm{P}=70 \%)$, Chrozophora tinctoria $(\mathrm{P}=30 \%)$, Emex spinosus and Lactuca serrula $(\mathrm{P}=10 \%)$. The plant cover ranges between 10 and $15 \%$. It is worthy to note that the majority of the recorded associates within this community seemed to be salt avoidance. Therefore their growth was restricted to favourable sites with low salinity.

Total buried seeds in the soil samples collected from this habitat have a value of 23352 seeds $/ \mathrm{m}^{2}$ and the emerged seedlings are 620 seedlings $/ \mathrm{m}^{2}$.

\section{2- Zygophyllum type album community}

The data presented in Table (3) clarify that the floristic composition of the vegetation dominated by Zygophyllum album consists of only five perennial and two ephemeral species. This community abounds on the dry saline habitats in the study area in which the soil surface is covered by salt crust. The plant cover is very thin and ranges between 5 and $10 \%$. In addition to the dominant species Zygophyllum album $(\mathrm{P}=100 \%)$, the layer of undershrubs and perennial herbs includes: Salsola imbricata and Cressa cretica $(\mathrm{P}=60 \%)$, Haloxylon salicornicum $(\mathrm{P}=40 \%)$ and cleome trinerva $(\mathrm{P}=20 \%)$. Bassia eriophora $(\mathrm{P}=80 \%)$ and Kochia indica $(\mathrm{P}=20 \%)$ are the two recorded ephemerals in this community. Samples collected from the upper $2 \mathrm{~cm}$ of soil supporting this community have buried seeds amounting to 15624 seeds $/ \mathrm{m}^{2}$, while the emerged seedlings are $200 / \mathrm{m}^{2}$.

\section{Discussion}

The present study has been focused on the inter relationships between vegetation characteristics and seed bank dynamics as affected by habitat diversity in the arid desert around Riyadh, Saudi Arabia.

A quite different four habitats were considered in this work. These habitats were found to have a functional topographic, edaphic and anthropogenic characteristics that contributed to composition, structure, and pattern of distribution of the recognized types of community and the buried seeds in the soil. The considered habitats were represented by depressions and terraces, runnels dissecting gravelly slopes, sandy plains and saline localities.

Within these habitats, eight community types were distingui-shed. Six communities were dominated by xerophytic species, while the other two communities were dominated by halophytic species. Species of xerophytic communities were dominated by species of: Francoeuria crispa, Lycium shawii and Farsetia aegyptia (in depressions and terraces), Cenchrus ciliaris and Lasiurus scindices (in affluent runnels) and Rhazya stricta (in sandy plains). Due to the anthropogenic effect, the salt-affected lands are increasing phenomenon in the study area. These saline habitats were occupied by communites dominated by halophytic species. Zygophyllum album community type was recorded in the dry saline habitat, whereas Tamarix nilotica community type was occurred in the wet saline habitat.

Plant cover of the studied communities was greatly influenced by soil texture. Comparatively high cover value was observed in the communities inhabiting depressions and terraces with relatively deep and finely textured soils possessing high water retaining capacity. Communities with high cover value were represented by: Francoeuria crispa (cover from 30 to 75\%) Lycium shawii (from 15 to 30\%) and Farsetia aegyptia (from 15 to $20 \%$ ). Meanuhile, open vegetation with low cover value (15\% or less) was observed in the communities inhabiting runnels of shallow and coarse-textured soil with low water 
retaining power. In arid regions, the water supply of plants depends upon the soil texture. Quantity of rain is only of indirect importance; the amount of water remaining in the soil and thus, available to plants is far more important (Walter 1979). Studies carried out by many investigators e.g Kassas and Imam (1954), Migahid et al., (1971), Batanouny (1979) and Zayed and El-Karemi, (1989) pointed out that plant cover was correlated to soil thickness. These explanations are in agreement with our observations in the present study.

The environmental stresses caused by the climatic aridity of the surveyed area together with excessive grazing and observed salinity stress were reflected remarkably on the composition and structure of the recorded community types. The permanent framework of the studied vegetation was generally composed of dwarf shrubs and perennial herbaceous species in which layering of vegetation was generally missed, it is only when the edaphic conditions are more favourable for plant growth, that the vegetation become more prosperous that shrubs and trees were encountered as that observed in Francoeuria crespa, Lycium shawii and Farsetia aegyptia community types.

The species density of the investigated community types was obviously low. The lowest species density of five perennial and two ephemeral species was recorded in the community dominated by Zygophyllum album inhabiting saline habitat. This can be explained by the statement that halophytes growing in saline arid zone are exposed to physiological and physical drought (Batanouny et al., 1992). On the other hand, species density of 14 perennial and 17 ephemeral species was recorded in the community dominated by Francoeuria crispa grown in depressions. It is to be noted that the limited number of the associated species, especially those of ephemeral ones, and the poverty of plant cover are manifestation of hostility of the habitat conditions (Kassas and Imam, 1959).

Reichman (1984) showed that from 80 to $90 \%$ of the seeds are present in the upper $2 \mathrm{~cm}$ of the soil. Seed bank is a part of vegetation (Willems, 1983). The present investigation revealed clearly that there was a great variablity of the seed bank within the different studied community types. The high value of seed bank in the soils collected from the communities inhabiting depression of deep soils were attributed to relative high cover value and high species density of the communites abounding on these habitats. On the other hand, very low value of seed bank of the soils collected from affluent runnels were mainly attributed to low cover value and excessive grazing which greatly reduced the seed productivity of the plants.

The present study revealed that the number of the seedlings emerged from the collected soil samples varied widely in the different studied community types. A high value of 2420 seedlings $/ \mathrm{m}^{2}$ was recorded in the soils collected from depressions supporting vegetation dominated by Francoeuria crispa. While a low value of only 150 seedlings $/ \mathrm{m}^{2}$ was obtained in the shallow runnels inhabited by Lasiurus scindicus community. In all studied cases the number of emerged seedlings represents a very low percentage ( 0.92 to $3.38 \%$ ) out of the total counted seeds. In other words a very large amount of the buried seeds failed to germinate. The ungerminated seeds represent what is called “deposit account” (Harper, 1977).

The results obtained are in agreement with that of Abd el-Rahman and Batanouny, 1959; Young and Evans, 1975; Zayed, 1980; Henderson et al., 1988; Baskin and Baskin, 1989; El-Yemeni and El-Farraj, 1995 and Emad, 1997. 
The present study showed that vegetation characteristics and seed bank dynamics were greatly affected and controlled by the prevailing environmental stress exerted on the distinguished habitats in the study area.

\section{References}

Abdel-Rahman, A. A. and K.H Batanouny. 1959. Germination of desert plants under different environmental conditions. Bull. Inst. Desert d' Egypte 9: 21-40.

Allen, S.E.; H.M. Grimshaw; J. M. Parkinson and C. Quarmby. 1974. Chemical Analysis of Ecological Materials. Oxford, Blackwell Scientific Publications. Pp 565.

Baierle, H.V.; A.M. EL-Sheikh and W. Frey. 1985. Vegetation und Flora im Mittleren Saudi Arabien (at Taif-arRiyadh). Beith. Tubinger Atlas Vorderer Orient Reich (Naturwissenschaftern). 22 wiesbaden.

Baskin, J. M. and C.C. Baskin. 1989. Seasonal changes in the germination reponses of buried seeds of Barbarea vulgaris. Con. J. Bot. 67: 2131-2134.

Batanouny, K.H. 1979. Vegetation along the Jeddah-Mecca road: Pattern and processes as affected by human impact. J. arid Environ. 2: 21-30.

Batanouny, K.H.; A.H. Hassan and G.M Fahmy. 1992. Ecophysiological studies on Halophytes in arid and semi-arid zones. II. Ecophysiology of Limoniun delicatum (GIR.) Ktze. Flora. 186: 1505-116.

Batanouny, K.H.; K.M. Zayed; , F.A. Marei and S. Adbel Gilel. 1991. The seed bank of arable lands in Egypt. Abstracta Botanica. 15: 19-24.

Braun-Blanquet, J. 1964. Pflanzensoziologie. Gustav. Fischer verlag. Wein.

Egly, G.H. 1986. Stimulation of weed seed germination in soil. Rev. Weed. Sci. 2: 67-89.

Emad, H. M. 1997. Ecology of the seed bank under desert conditions. Ph.D. thesis Bot. Dept. Fac. Sci. Cairo Univ. pp. 277.

EL-Yemeni, M. and M.M. El-Farraj. 1995. The seed bank of desert soil in central Saudi Arabia. Pak. J. Bot. 27 (2): 30g-31g.

El-Yemeni, M and K.M. Zayed. 1999. Ecology of some plant communities along Riyadh Al-Thumamah road, Saudi Arabia. J. Saudi, Biol. Soc. (in press).

EL-Farraj, M.M.; A. El-Farhan, and M. EL-Yemeni. 1997. Ecological studies on Rawdhat system in Saudi Arabia. I-Rawdhat Khorim-Pak. J. Bot. 29(1): 75-88.

Harper, J. L. 1977. The population biology of plant. Academic press. London.

Henderson, C.B.; K.E. Petersen, and R. A. Redak. 1988. Spatial and temporal patterns in the seed bank and vegetation of a desert grassland community. J. Ecol. 76: 717-728.

Kassas, M. and M. Imam. 1954. Habitats and plant communities in the Egyptian desert. III. The wadi bed Ecosystem. J. Ecol. 42: 424-441.

Kassas, M. and M. Imam. 1959. Habitat and plant communities in the Egyptian desert. IV. The gravel desert. J. Ecol. 47: 289-310.

Kemp, P. R. 1989. Seed banks and vegetation processes in deserts. In: Leck, M.A.; Parker, V.T. and Simpson, R.L., (Eds.), Ecology of soil seed banks. Academic press Inc.

Khattab, A. and M.N. El-Hadidi. 1971. Results of a botanic expedition to Arabia in 194445. Publ. Cairo Univ. Herb. 4: 95 pp.

Malone, C.R. 1967. A rapid method for the enumeration of viable seeds in the soil-weeds. 15: $381-382$. 
Migahid, A.M. and A.M. El-Sheikh. 1977. Types of desert habitats and their vegetation in Central and Eastern Arabia. Proc. Saudi . Biol. Soc. 1: 5-13.

Migahid, A.M.; K.H. Batanouny and M.A. Zaki. 1970. Phytosociological and Ecological study of a sector in the Mediterranean coastal region in Egypt. Vegetatio: 23: 133-143.

Piper, C.S. 1950. Soil and Plant Analysis. Inter Science publ.

Reichman, O.J. 1984. Spatiol and temporal variation of seed distribution in Sonoran desert soils. J. Biogeogr. 11: 1-11.

Roberts, H. A. 1981. Seed banks in soil Adv. App. Biol. 6: 1-55.

Roberts, H. A and P.M. Feast. 1972. Fate of seeds of some annual weeds in different depths of cultivated and undisturbed soil. Weed Res. 12: 181-190.

Roberts, H. A and J. Neilson. 1982. Seed banks of soils under vegetable cropping in England. Weed Res. 22: 13-16.

Vesey-Fitzgerald, D.F. 1957b. The vegetation of Central and Eastern Arabia. J. Ecol. 45: 779-789.

Vesser, J. H. and L.F. Wentzel. 1980. Quantitative estimation of Alectra and Striga seed in soil. Weed Res. 20: 77-81.

Walter, H. 1979. Vegetation of The Earth and Ecological System of The Geo-Biosphere, $2^{\text {nd }}$ ed. Springer-Verlag. New York, Heidelberg, Berlin. Pp 267.

Willems, J. H. 1983. Seed bank and vegetation. Acta Bot. Neeslandica. 3: 243-247.

Young, J. A. and R. A. Evans. 1975. Germinability of seed reserves in a big sagebrush community. Weed Sci. 23: 358-364.

Yousif, M. A. and A. M. El-Sheikh. 1982. Observations of gravel desert areas with special reference to succession in Central Saudi Arabia. J. Coll. Sci. Univ. Riyadh. 12(2): 331-351.

Zayed, K. M. 1980. Ecophysiological Studies on Some Desert Plants. Ph.D. Thesis Cario Univ. pp. 232.

Zayed, K.M. and A. R. El-Karemi. 1989. Vegetation between Taif and El-Shafa highand (Asir mountains, Saudi Arabia. Feddes Repertorium 100 (11). 12: 661-672. 